\title{
Sternal wound infections following cardiac surgery and their management: a single-centre study from the years 2016-2017
}

\author{
Agnieszka Kotnis-Gąska1, Piotr Mazur ${ }^{2,3}$, Aldona Olechowska-Jarząb ${ }^{1}$, Andrzej Stanisz ${ }^{4}$, \\ Małgorzata Bulanda ${ }^{5}$, Anetta Undas ${ }^{1,3}$
}

${ }^{1}$ Center for Innovative Laboratory Diagnostics, John Paul II Hospital, Krakow, Poland

${ }^{2}$ Department of Cardiovascular Surgery and Transplantology, Institute of Cardiology, Jagiellonian University Medical College, Krakow, Poland ${ }^{3}$ Institute of Cardiology, Jagiellonian University Medical College, Krakow, Poland ${ }^{4}$ Department of Bioinformatic and Telemedicine, Jagiellonian University Medical College, Krakow, Poland ${ }^{5}$ Chair of Microbiology, Faculty of Medicine, Jagiellonian University Medical College, Krakow, Poland

Kardiochirugia i Torakochirurgia Polska 2018; 15 (2): 79-85

\begin{abstract}
Introduction: Despite improvements in surgical management, sternal wound infection (SWI) following cardiac surgery remains a significant complication.

Aim: To evaluate pathogens involved in SWI following median sternotomy.

Material and methods: We enrolled 164 patients who experienced prolonged sternal wound healing following open-heart surgery. The inclusion criteria were as follows: prolonged sternal wound healing following cardiac surgery via median sternotomy and complete results of microbiological culture obtained from the sternal swab. The exclusion criteria were as follows: partial sternotomy, patients with mechanical sternum dehiscence and incomplete clinical data. Swabs provided information on the type of microorganism present in the wound and the susceptibility of the microorganism to specific antibiotics.

Results: One hundred and fourteen (69.5\%) patients aged 68 (interquartile range: $60-76)$ years developed SWI with positive culture. The in-hospital mortality rate was $21.0 \%$ in this group. The most common pathogens included Staphylococcus epidermidis (26.6\%), Enterococcus faecium (12.2\%), Staphylococcus aureus (11.4\%), Klebsiella pneumoniae (8.4\%), and Pseudomonas aeruginosa (6.8\%). In most of the cases the isolated Staphylococcus epidermidis was methicillin-resistant ( $n=57,43.5 \%$ ). Enterococcus faecium was vancomycin-resistant in 11 (8.3\%) cases and high-level aminoglycoside resistant (HLAR) in 13 (9.9\%) cases. Klebsiella pneumoniae had the extended-spectrum $\beta$-lactamase (ESBL) mechanism in 14 (10.6\%) cases. Among 114 culture-positive patients, 48 (42.1\%) had polymicrobial infection of the sternal wound.

Conclusions: Microorganisms associated with SWI in our study were mainly commensals, with the most common pathogen being Staphylococcus epidermidis.
\end{abstract}

Key words: sternal wound infection, cardiac surgery.

\section{Streszczenie}

Wstęp: Pomimo udoskonaleń w procedurach chirurgicznych nadal głównym powikłaniem po operacjach kardiochirurgicznych są zakażenia ran mostka.

Cel: Ocena patogenów, które wywołują zakażenia ran mostka po sternotomii pośrodkowej.

Materiat i metody: Do badania włączono 164 pacjentów, u których stwierdzono przedłużone gojenie rany mostka po operacji kardiochirurgicznej. Kryteria włączenia stanowiły przedłużone gojenie się rany mostka po operacji kardiochirurgicznej z dostępu przez sternotomię pośrodkową i kompletne wyniki hodowli mikrobiologicznej uzyskane z wymazu z mostka, natomiast kryteria wyłączenia - częściowa sternotomia, mechaniczne rozejście się mostka i niekompletne dane kliniczne. Mikroorganizmy były identyfikowane za pomocą hodowli mikrobiologicznej, na podstawie której określano także ich lekowrażliwość.

Wyniki: U 114 (69,5\%) pacjentów w wieku 68 lat (rozstęp międzykwartylowy: 60-76) doszło do zakażenia rany mostka. Śmiertelność w tej grupie wynosiła 21\%. Najczęściej izolowane patogeny to: Staphylococcus epidermidis (26,6\%), Enterococcus faecium $(12,2 \%)$, Staphylococcus aureus (11,4\%), Klebsiella pneumoniae (8,4\%), Pseudomonas aeruginosa (6,8\%). Większość wyizolowanych szczepów Staphylococcus epidermidis była metycylinooporna -57 (43,5\%). Enterococcus faecium był oporny na glikopeptydy w 11 (8,3\%) przypadkach oraz na duże stężenia antybiotyków aminoglikozydowych w 13 (9,9\%) przypadkach. Klebsiella pneumoniae wytwarzała $\beta$-laktamazy o rozszerzonym spektrum substratowym (ESBL) w 14 (10,6\%) przypadkach. Spośród 114 pacjentów z dodatnim wynikiem posiewu w 48 (42,1\%) przypadkach odnotowano infekcje wielopatogenowe.

Wnioski: Mikroorganizmy powodujące wyżej wymienione zakażenia to głównie komensale, a najczęściej występującym patogenem był Staphylococcus epidermidis.

Słowa kluczowe: zakażenia ran mostka, operacja kardiochirurgiczna.

Address for correspondence: Agnieszka Kotnis-Gąska, Center for Innovative Laboratory Diagnostics, John Paul II Hospital, 80 Prądnicka St, 31-202 Krakow, Poland, phone: +48 1261431 46, e-mail: a.kotnis@szpitaljp2.krakow.pl

Received: 24.01.2018, accepted: 28.05.2018. 


\section{Introduction}

Patients undergoing cardiac surgical procedures using sternotomy have significant risk of sternal wound infection (SWI). Superficial sternal wound infection (SSWI), which involves the skin, subcutaneous tissue and the pectoralis fascia, has an incidence of $0.5 \%$ to $8 \%$, with an associated morbidity and mortality rate ranging from $0.5 \%$ to $9 \%$ $[1,2]$. Superficial sternal wound infection are often completely eradicated with intravenous antibiotics and local wound care. The incidence of deep sternal wound infection (DSWI), despite advances in prevention, still remains significant, and ranges between $0.5 \%$ and $6.8 \%$ [3-5], with in-hospital mortality rates between $7 \%$ and $47 \%$ [3-5]. In many cases, traditional markers of infection such as fever, leucocytosis and C-reactive protein (CRP) have proved unreliable [6]. Some patients require further surgery, including repeated debridement and major surgical reconstruction. It has been reported that there are several risk factors of DSWI, including obesity, chronic obstructive pulmonary disease (COPD), prolonged ventilation, previous cardiac surgery, diabetes mellitus (DM), re-exploration for bleeding, age, length of stay, reperfusion syndrome, type of procedure (coronary artery bypass graft surgery (CABG) or valve replacement/repair (VR)), type of admission to hospital, type of discharge, postoperative blood transfusion, and osteoporosis [1, 7-9].

After surgery, many wounds are infected with the endogenous patient pathogens. Deep sternal wound infection usually present with systemic signs of infection or local signs, such as chest pain and wound discharge [10]. Swabs, or preferably pus, obtained directly from the wound or abscess, are recommended to identify the causative pathogen. Commonly occurring microorganisms responsible for hospital wound infection are Staphylococcus aureus, Streptococcus pyogenes, Escherichia coli, Proteus spp., anaerobes, Enterococcus spp. and coagulase-negative staphylococci (CoNS) [11]. Recent reports have shown a growing number of DSWI caused by methicillin-resistant (MR) Gram-positive pathogens, especially Staphylococcus epidermidis, which is one of the most common bacteria in post-sternotomy mediastinitis, and about $75 \%$ of strains are MR [4].

Surveillance data for surgical site infection (SSI) from 16 countries that comprised 422,201 surgical operations from 1,332 hospitals published in 2012 showed that the most common pathogens identified in wounds following CABG are Gram-positive cocci (60.3\%) (Staphylococcus aureus - $26.7 \%)$, CoNS (24.6\%) and Gram-negative bacilli Enterobacteriaceae (23.0\%) [12].

The interpretation of bacteriological findings still depends on the quality of the specimens analysed and could be challenging [13].

The treatment of DSWI poses major problems leading to high mortality and poor outcomes of conventional wound management techniques and new approaches to therapy. The standard medical treatment for DSWI includes antibiotics, surgical debridement, re-suturing and negative pressure wound therapy (NPWT). Debridement followed by the placement of a wound vacuum-assisted closure (VAC) is a commonly used and effective DSWI treatment in recent years [10]. The VAC therapy system replaced most of the conventional types of wound treatment due to the faster wound healing, shorter length of hospital stay and lower in-hospital cost. The currently available data suggest a lower mortality rate and support the use of VAC therapy for treatment of patients with DSWI following cardiac surgery, but the effect of VAC on the length of stay (LOS) and the cost should be further investigated [14]. In some cases, the use of hyperbaric oxygen therapy $\left(\mathrm{HBO}_{2}\right)$ in patients with DSWI after surgery might be helpful to cure the infection. Litwinowicz et al. [3] showed that $\mathrm{HBO}_{2}$ as an additional therapy in DSWI was successful in $80 \%$ of cases.

\section{Aim}

The aim of the study was to evaluate pathogens involved in SWI following median sternotomy.

\section{Material and methods}

Between $1^{\text {st }}$ January 2016 and 315t May 2017, 2986 operations were performed at the Department of Cardiovascular Surgery and Transplantology, the John Paul II Hospital, Krakow, Poland. In this retrospective study, we enrolled 164 patients aged $\geq 18$ years. The inclusion criteria were as follows: a prolonged sternal wound healing following cardiac surgery via median sternotomy and complete results of microbiological culture obtained from the sternal swab. The exclusion criteria were as follows: partial sternotomy, patients with mechanical sternum dehiscence and incomplete clinical data. All postoperative sternal wound complications were referred back to our department from other hospitals and rehabilitation facilities. All patients who underwent surgery in the study period were screened. The total number of patients included in this study was 164. We divided the patients into two groups, based on the culture results: the SWI group (pathogen identified) and a negative culture group.

Data on demographics, comorbidities, type of hospital admission (elective, urgent or emergency), risk factors and causative pathogens, and therapeutic modes, in particular antibiotic treatment, drainage system, VAC, and gentamicin-collagen sponge use, were collected based on medical records. Antibiotics are not routinely prescribed for home use or prescribed at discharge from our department. Only patients with confirmed or suspected infection continue treatment after discharge.

Standardized anaesthetic and surgical procedures were applied in all cases. Perioperative antibiotic prophylaxis comprised cefazolin $4 \times 2 \mathrm{~g}$ i.v. within $24 \mathrm{~h}$ (the first dose preoperatively, infusion being completed 60-30 min before skin incision); if the operation was prolonged, another dose was added to the cardiopulmonary bypass (CPB). In patients with documented $\beta$-lactam allergies, clindamycin was given $3 \times 600 \mathrm{mg}$ i.v. within $24 \mathrm{~h}$, following the same protocol. Individuals with documented methicillin-resistant Staphylococcus aureus (MRSA) colonization received vancomycin $2 \times 1 \mathrm{~g}$ i.v. (the pre-operative infusion of $1 \mathrm{~h}$ dura- 
tion had to be completed at least 60 min preoperatively). Skin preparation included pre-operative bathing with soap and hair removal by means of clipping. In the operating room, directly before the onset of the surgical procedure, the skin preparation was performed 4 times (once in the anaesthesia preparation room, and 3 times in the operating room before draping) using the coloured antiseptic solution (Kodan Tinktur forte coloured, Schülke \& Mayr, Norderstedt, Germany). Draping followed no sooner than 3 min after the last skin preparation. All patients underwent an operation through a full or mini-sternotomy, with CPB, which was performed in hypothermia according to the surgeons' preference (oesophageal temperature, $28-34^{\circ} \mathrm{C}$ ) using a non-pulsatile roller pump and a $40 \mu \mathrm{m}$ arterial blood filter (both, Jostra Medizintechnik AG, Hirrlingen, Germany), with blood flow of $2.0-2.4 \mathrm{l} / \mathrm{min} / \mathrm{m}^{2}$ and mean arterial pressure of $40-60 \mathrm{~mm} \mathrm{Hg}$. Diabetic patients, or those at high risk of infection, as assessed by the surgeon, received a gentamycin-collagen sponge (Garamycin, EUSA Pharma, Hemel Hempstead, UK). All patients were transferred to the intensive care unit for postoperative ventilation, and were extubated following the standard criteria.

The diagnosis of wound infection was confirmed by the positive bacterial culture results. Wound swabs were collected and empiric antibiotic therapy was indicated. Before the swab from the wound was collected, the wound edges were disinfected with alcohol or disinfectant. The material was taken from the border and the central part of the wound, trying to erase about $1 \mathrm{~cm}^{2}$. From deep wounds the material was collected by puncture with a needle and syringe. Aspirated material was introduced into the transport medium, and after being properly sealed it was transported to the laboratory in special thermostatic transport containers within $2 \mathrm{~h}$. The pathogens were grown on the prepared selective culture media: MacConkey agar and Columbia agar with $5 \%$ sheep blood (bioMérieux, France) at $35-37^{\circ} \mathrm{C}$ for $18-24 \mathrm{~h}$ according to the local procedures. Additionally, chromogenic medium for selective isolation and direct identification of Staphylococcus aureus was used (CHROMID Staphylococcus aureus Elite agar - SAIDE; bioMérieux, Marcy l'Etoile, France). Sabouraud agar medium (bioMérieux, Marcy l'Etoile, France) was used for detection of fungal infection, incubated at $35-37^{\circ} \mathrm{C}$ for 7 days. The VITEK 2 Compact (bioMérieux, Marcy l'Etoile, France) automated identification system was used for determination of the antibiotic susceptibility, according to the clinical and laboratory standards. The susceptibility profile of the organism cultured from the sternal wound was sent back to the managing physician. In 114 cases culture reports and antibiotic susceptibility tests showed bacterial or bacterialfungal flora. Targeted antibiotic therapy was performed based on the microbiology results and was carried out in cooperation with the hospital infection team.

\section{Statistical analysis}

Statistica version 13.0 (StatSoft) was used for statistical analysis. Categorical variables were expressed as numbers and percentages, while other data were presented as median and interquartile range. The Shapiro-Wilk test to assess the normality of the variable distribution. Differences between nominal variables were analysed with the $\chi^{2}$ test. The non-parametric Mann-Whitney $U$ test was used for further analysis due to the non-normal distribution of continuous variables. A $p$-value less than 0.05 was considered significant.

\section{Results}

A total 164 patients were clinically diagnosed with prolonged wound healing (Table I), and were included in the final analysis, including 114 (69.5\%) patients with a positive culture from a sternal wound and 50 (30.5\%) patients with a negative culture, who served as a negative culture group. In both groups, there were patients who experienced prolonged sternal wound healing. The majority of patients were men ( $n=128,78 \%)$, aged over 50 years. Patients had various comorbidities, including COPD $(n=24$, $14.6 \%)$, DM ( $n=64,39.0 \%)$, chronic kidney disease (CKD) ( $n=34,20.7 \%)$, malignancy $(n=8,4.9 \%)$, and obesity $(n=67,40.8 \%)$ (Table I). There were 75 (45.7\%) patients following CABG, 51 (31.1\%) patients following VR, 18 (11.0\%) patients following CABG combined with VR, and 5 (3.1\%) patients following aortic aneurysm treatment. At the index procedure, 61 (37.2\%) subjects received a gentamicin-collagen sponge. All of the patients were treated with antibiotics upon diagnosis of prolonged wound healing (initiated upon swab collection), while 59 (36.0\%) patients were additionally treated with the drainage system, and 68 (41.4\%) individuals underwent the VAC therapy. One (0.6\%) patient underwent additional $\mathrm{HBO}_{2}$ treatment.

\section{Hyperbaric oxygen management}

The patient who underwent $\mathrm{HBO}_{2}$ treatment was a 75-year-old man, with DM, after aortic and mitral valve replacements. He was admitted back to hospital after 1898 days post-procedurally, with the symptoms of SWI. Polymicrobial infection was observed, and the identified pathogens included MR Staphylococcus epidermidis, MR Staphylococcus haemolyticus, Pseudomonas aeruginosa and Serratia marcescens. After several revisions of the sternal wound due to impaired healing, usage of VAC and targeted antibiotic therapy, the decision was made to start the treatment in the hyperbaric chamber, with a good outcome. The patient was discharged in good condition with the wound healed.

\section{Comparison of patients with and without positive wound cultures}

There were no differences between the SWI group and the negative culture group with respect to age, sex, comorbidities, time since the index procedures, smoking status, American Society of Anaesthesiologists (ASA) score, or type and duration of surgery (Table I). There was a significant difference in the VAC treatment between the groups: in the 
Table I. Baseline characteristics of study groups

\begin{tabular}{|c|c|c|c|c|}
\hline Variable & $\begin{array}{c}\text { Total } \\
(n=164)\end{array}$ & $\begin{array}{l}\text { Negative culture } \\
\text { group } \\
n=50(30.5 \%)\end{array}$ & $\begin{array}{c}\text { SWI group } \\
n=114(69.5 \%)\end{array}$ & $P$-value \\
\hline Age, median (IQR) [years] & & $66.5(59-75)$ & $68.0(60-76)$ & 0.55 \\
\hline Male sex, $n(\%)$ & $128(78.0)$ & $42(84.0)$ & $86(75.4)$ & 0.22 \\
\hline Type of hospital admission: planned admission, $n$ (\%) & $86(52.4)$ & $20(40.0)$ & $66(57.9)$ & 0.002 \\
\hline Time since the index procedure, median (IQR) [days] & & $20(7-42)$ & $21(12-39)$ & 0.69 \\
\hline Hospital stay, median (IQR) [days] & & $20.5(8-56)$ & $35.5(19-54)$ & 0.012 \\
\hline Current smokers, $n(\%)$ & $19.0(12.3)$ & $8(16.7)$ & $11(10.4)$ & 0.27 \\
\hline \multicolumn{5}{|l|}{ Surgical procedure: } \\
\hline CABG, $n(\%)$ & $75(45.7)$ & $19(38.0)$ & $56(34.2)$ & 0.64 \\
\hline Valve replacement/repair isolated, $n$ (\%) & $51(31.1)$ & $16(32.0)$ & $35(30.7)$ & 0.87 \\
\hline CABG and valve replacement/repair combined, $n$ (\%) & $18(11.0)$ & $6(12.0)$ & $12(10.5)$ & 0.78 \\
\hline Aortic aneurysm, $n(\%)$ & $5(3.1)$ & $2(4.0)$ & $3(2.6)$ & 0.64 \\
\hline LVAD, $n(\%)$ & $3(1.8)$ & $3(6.0)$ & $0(0.0)$ & 0.008 \\
\hline Other procedures*, $n(\%)$ & $12(7.3)$ & $4(8.0)$ & $8(7.0)$ & 0.82 \\
\hline Non-clean operation, $n$ (\%) & $3(2.0)$ & $1(2.3)$ & $2(1.9)$ & 0.87 \\
\hline ASA score, $n$ (\%) III; IV; V & \multicolumn{2}{|c|}{11 (25.6); 30 (69.8); 2 (4.7) } & 38 (36.2); 62 (59); 5 (4.8) & 0.45 \\
\hline Duration of operation [min] & & $275(220-330)$ & $270(225-330)$ & 0.88 \\
\hline \multicolumn{5}{|l|}{ Therapy used, $n(\%)$ : } \\
\hline Vacuum-assisted closure & $68(41.4)$ & $6(12.0)$ & $62(54.4)$ & $<0.001$ \\
\hline Gentamicin-collagen sponge & $61(37.2)$ & $15(30.0)$ & $46(40.4)$ & 0.21 \\
\hline Drainage system & $59(36.0)$ & $18(36.0)$ & $41(36.0)$ & 0.99 \\
\hline \multicolumn{5}{|l|}{ Comorbidities, $n$ (\%): } \\
\hline Cardiovascular disease & $155(94.5)$ & $50(100)$ & $105(92.1)$ & 0.041 \\
\hline Chronic obstructive pulmonary disease & $24(14.6)$ & $4(8.0)$ & $20(17.5)$ & 0.11 \\
\hline Diabetes mellitus & $64(39.0)$ & 19 (39.6) & $45(42.5)$ & 0.74 \\
\hline Chronic kidney disease & $34(20.7)$ & $9(18.0)$ & $25(22.0)$ & 0.57 \\
\hline Malignancy & $8(4.9)$ & $3(6.0)$ & $5(4.4)$ & 0.66 \\
\hline Obesity & $67(40.8)$ & $18(37.5)$ & $49(46.2)$ & 0.32 \\
\hline Alcoholism & $5(3.0)$ & $2(4.2)$ & $3(2.8)$ & 0.66 \\
\hline Survival & $135(82)$ & $45(90)$ & $90(79)$ & 0.09 \\
\hline
\end{tabular}

Data are presented as number (percentage) for categorical variables, or as median (interquartile range (IQR)) for continuous variables. CABG - coronary artery bypass graft surgery, LVAD - left ventricular assist device, ASA - American Society of Anaesthesiologists (ASA) score, *other procedures included: pericardiectomy, cardiac tumour removal, pericardiocentesis, cardiac tamponade.

SWI group VAC was used more than 4 times as frequently compared to the negative culture group (62 (54.4\%) vs. 6 (12.0\%), $p<0.001)$. Patients from the SWI group had mean hospital length of stay (LOS) of 35.5 days vs. 20.5 days in the remainder $(p=0.01)$. Death before discharge occurred in 29 (17.7\%) cases in both groups: 5 (3\%) patients in the negative culture group and 24 (14.6\%) patients in the SWI group.

\section{Identified pathogens}

The most common pathogens in order of decreasing prevalence included Staphylococcus epidermidis (26.6\%), Enterococcus faecium (12.2\%), Staphylococcus aureus (11.4\%), Klebsiella pneumoniae (8.4\%), and Pseudomonas aeruginosa $(6.8 \%)$. The spectrum of causative pathogens is shown in Figure 1. In most of the cases isolated Staphylococcus epidermidis was MR, $n=57$ (43.5\%) (Table II). Enterococ- 
Table II. The most common pathogens isolated from the sternal wounds of 114 cardiac patients and their mechanisms of antimicrobial resistance

\begin{tabular}{|c|c|c|c|c|c|c|c|c|c|}
\hline \multirow[t]{2}{*}{ Causative pathogens } & \multicolumn{9}{|c|}{ Mechanisms of antimicrobial resistance in bacteria, $n$ (\%) } \\
\hline & MR & MS & ESBL & VRE & HLAR & XDR & MDR & None & Negative \\
\hline Staphylococcus epidermidis & $57(43.5)$ & $3(2.2)$ & & & & & & $1(0.7)$ & $70(53.4)$ \\
\hline Enterococcus faecium & & & & $11(8.3)$ & $13(9.9)$ & & & $6(4.5)$ & $101(77.0)$ \\
\hline Staphylococcus aureus & $4(3.0)$ & $17(12.9)$ & & & & & & $1(0.7)$ & $109(83.2)$ \\
\hline Klebsiella pneumoniae & & & $14(10.6)$ & & & & & $5(3.8)$ & $112(85.4)$ \\
\hline Pseudomonas aeruginosa & & & & & & $2(1.5)$ & $3(2.2)$ & $12(9.1)$ & $114(87.0)$ \\
\hline Staphylococcus hominis & $12(9.1)$ & & & & & & & & $119(90.8)$ \\
\hline Staphylococcus haemolyticus & $9(6.8)$ & & & & & & & & $122(93.1)$ \\
\hline Enterobacter cloacae & & & $5(3.8)$ & & & & & $5(3.8)$ & $121(92.3)$ \\
\hline Enterococcus faecalis & & & & $1(0.7)$ & $5(3.8)$ & & & $2(1.5)$ & $123(93.8)$ \\
\hline Proteus mirabilis & & & $1(0.7)$ & & & & & $4(3.0)$ & $126(96.1)$ \\
\hline
\end{tabular}

MR - methicillin-resistant, MS - methicillin-sensitive, ESBL - extended-spectrum $\beta$-lactamases, VRE - vancomycin-resistant Enterococcus, HLAR - high-level aminoglycoside resistance, XDR - extensively drug-resistant, MDR - multidrug-resistant. Data are presented as $n$ (\%) unless indicated otherwise. None - without a resistance mechanism. This group accounted for $84.8 \%$ of all pathogens found in sternal wounds.

cus faecium was vancomycin-resistant in 11 (8.3\%) cases and high-level aminoglycoside resistant (HLAR) in 13 (9.9\%) cases. Klebsiella pneumoniae had the extended-spectrum $\beta$-lactamases (ESBL) mechanism in $14(10.6 \%)$ cases. The mechanisms of antimicrobial resistance in bacteria are presented in Table II.

\section{Polymicrobial infections}

Among 114 culture-positive patients, 48 (42.1\%) had polymicrobial infection of the sternal wound. The risk of polymicrobial SWI was increased with obesity $(\mathrm{OR}=$ 3.17, 95\% Cl: 1.39-7.21, $p=0.005)$, longer LOS (OR = 1.03, $95 \% \mathrm{Cl}: 1.01-1.05, p=0.0002)$, and $\mathrm{DM}(\mathrm{OR}=3.52$, $95 \% \mathrm{Cl}: 1.53-8.05, p=0.003)$. Smoking, alcoholism and age had no significant effect on the occurrence of polymicrobial infection.

\section{Polymicrobial infection with pandrug-resistant (PDR) Klebsiella pneumoniae}

One case of polymicrobial infection followed by an infection with PDR Klebsiella pneumoniae was a 62-year-old obese woman with acute coronary syndrome, who underwent urgent $C A B G$ in our hospital. She was preoperatively diagnosed with hypertension, severe COPD, DM on insulin and CKD. The surgery and early postoperative course were uneventful, and the patient was discharged on day 7 postoperatively to the rehabilitation facility. About 10 days after the surgery, the patient complained of sternal pain, purulent discharge, and sternal instability, but remained afebrile. She was re-admitted, and Enterococcus faecalis was found in the wound swab. Antibiotic therapy was initiated.

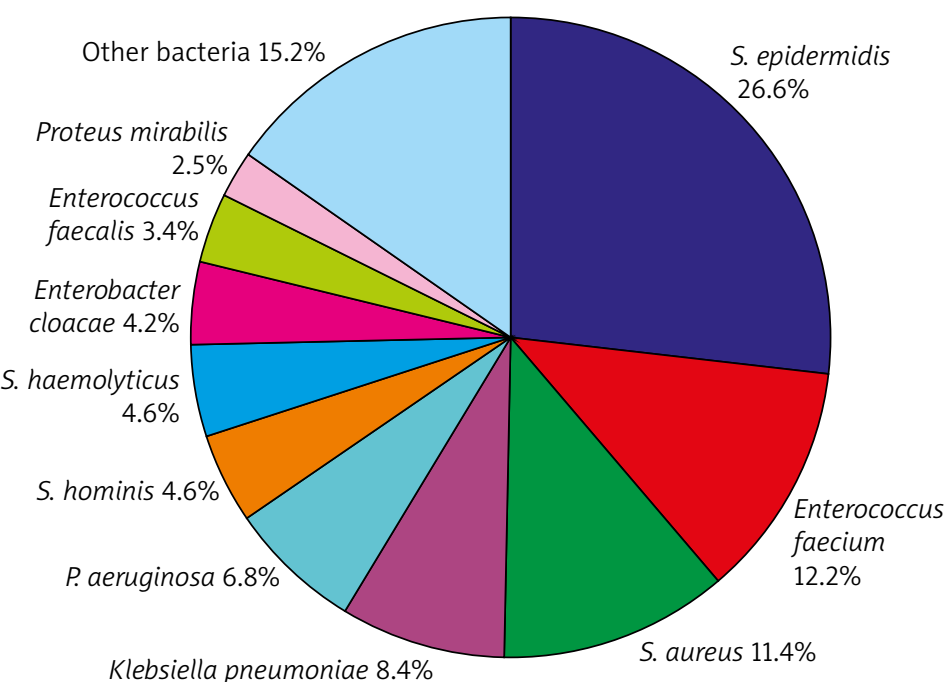

Fig. 1. Frequency of all causative pathogens isolated in the patients with the SWI. ${ }^{*}$ Other bacteria and fungi: Acinetobacter baumannii, Candida albicans, Escherichia coli, Serratia marcescens, Morganella morganii, Gemella morbillorum, Listeria monocytogenes, Klebsiella oxytoca, Citrobacter freundii, Granulicatella elegans

The VAC system was used and additional material from the wound was sent to the laboratory, where two microorganisms were identified: MR Staphylococcus epidermidis and Staphylococcus haemolyticus. Additionally, 3 days after the specimen was obtained, Klebsiella pneumoniae with the ESBL mechanism was revealed. After several VAC dressing changes, the sternum was closed, and wound drainage was started with Microdacyn 60 Wound Care (Sonoma 
Pharmaceuticals, Petaluma, CA, USA); however, the wound still presented signs of infection and purulent exudate was noted. Another wound swab was collected and found to be positive for Enterococcus faecium with HLAR, vancomycinresistant Enterococcus and Candida albicans. During further management the patient became febrile $\left(39^{\circ} \mathrm{C}\right)$, and extensive blood cultures were collected, which were positive for Candida parapsilosis. The patient was transferred to the ICU, where medical, antimicrobial and antifungal management followed. After another 3 weeks, the blood culture revealed PDR and ESBL Klebsiella pneumoniae, the first case in our institution with PDR Klebsiella pneumoniae, as non-susceptible to all agents in all antimicrobial categories. The patient received multidrug antibiotic therapy (linezolid, vancomycin, meropenem, colistin, tobramycin, piperacillintazobactam), and stayed in the ICU for 77 days. Afterwards, she was transferred to the local hospital for further management. She was unconscious and intubated, but haemodynamically stable on the day of her transfer.

\section{Clostridial diarrhoea}

Among 164 patients who were included in this study, 38 (23.1\%) were tested for Clostridium difficile toxins A/B and an antigen test (C. DIFF QUIK CHEK COMPLETE; TechLab/Wampole, Alere, USA); 8 (4.8\%) were positive for glutamate dehydrogenase (GDH) and toxins A/B, 5 (3.0\%) patients had positive GDH but negative results for toxin $A / B$, and 25 (15.2\%) were negative for both parameters.

\section{Discussion}

This study documents that Staphylococcus epidermidis, Enterococcus faecium, Staphylococcus aureus, Klebsiella pneumoniae and Pseudomonas aeruginosa are the most common SWI causative organisms following cardiac surgery. We report that obesity and DM, along with extended LOS, increase the chance of polymicrobial wound infection.

Several studies have evaluated the pathogen spectrum in SWI patients after heart operations. Chaudhuri et al. [15] showed that Staphylococcus aureus was the commonest organism cultured from deep sternal tissue (39\%), in their study performed between 2005 and 2011. Half of the cultured organisms were methicillin-susceptible, followed by CoNS (27\%), while Gram-negative organisms were cultured in less than a quarter of patients (23\%). Pseudomonas aeruginosa was the most common Gram-negative organism isolated across samples (6\%). None of the Gram-negative organisms identified possessed extended-spectrum $\beta$-lactamases [15]. The pathogen spectrum in SWI may differ between hospitals; for example, in our hospital Staphylococcus epidermidis was the main causative pathogen of infection, 26.6\% during the study period (Fig. 1). In 57 (43.5\%) cases Staphylococcus epidermidis was MR. Moinipoor et al. [16] in their study had 82 (1.7\%) cases of DSWI, with mortality rates in patients with and without infection of $10.9 \%$ and $6.7 \%$. The causative organisms were Klebsiella, Pseudomonas, CoNS, Acinetobacter, Staphylococcus aureus, Escherichia coli, and MR Staphylococcus aureus [16].
Klebsiella was the most common isolated pathogen, which can be attributed to the lack of routine prophylactic antibiotics for Gram-negative coverage in high-risk patients in this institution [16]. The mortality rates in individuals with and without infection were $14.6 \%$ and $3.0 \%$ in our hospital. Additionally, in our institution perioperative antibiotic prophylaxis consisting of cefazolin was used. In our study, Klebsiella pneumoniae accounted for $8.4 \%$ of all infections, in 14 cases with the ESBL mechanism. The knowledge of pathogens existing in hospitals might help to protect patients against them by the application of prophylaxis. The correctly tailored empirical antimicrobial therapy may help to reduce infections.

The different types of SSI are persistent and preventable health care-associated infections. Before surgery, patients should shower with soap or an antiseptic agent, antimicrobial prophylaxis should be administered only when indicated, skin preparation in the operating room should be performed using an alcohol-based agent, and glycaemic control should be implemented [17]. The number of surgical procedures performed worldwide continues to rise, and patients who undergo surgical procedures are getting older and have additionally different underlying conditions (ASA scores of III, IV and even V are frequent, especially among cardiac patients) [18]. In our study, 62 (59) patients from the SWI group were assigned an ASA score of IV. One percent of patients who have median sternotomy develop SSWI usually 7-9 days after the operation [6]. In our study, 2.4\% the patients developed SSWI usually 7-9 days post-operatively. DSWI usually presents 2-4 weeks after an operation, but can present months or years later [6]. Among the 164 patients enrolled in this study, 107 (65.2\%) developed DSWI. Symptoms occurred on average 21 (12-39) days after the index procedure. Incidence of SWI as a complication of major cardiac surgery was estimated to be around 3.5\% in our study. Our incidence of SWI was consistent with the results of published literature.

Porubnicova et al. [8] identified that polymicrobial DSWI were more frequent in older patients, patients with the duration of extracorporeal circulation exceeding $120 \mathrm{~min}$, longer postoperative hospital stay, in patients readmitted from another hospital after initial discharge and in obese patients. Microorganisms that colonize the damaged tissues often form polymicrobial communities called biofilms. This structure protects them from the host immune system and gives them resistance to antibiotic treatment [19]. In our study, 48 (42.1\%) patients from the SWI group had polymicrobial infections. Among patients with SWI was 1 woman with polymicrobial infection who additionally developed a blood infection and had a positive blood culture for PDR Klebsiella pneumoniae. It was the first case in our hospital. The wound was successfully healed and the patient was transferred to the local hospital for further management.

Cardiac patients differ from those undergoing noncardiac surgery in the use of cardiopulmonary bypass and systemic hypothermia, the relatively long operating times, and the frequent use of central venous access and indwell- 
ing catheters. These differences may encourage the use of prophylactic antibiotics for an extended period of time. Unfortunately, prolonged antibiotic use $>48 \mathrm{~h}$ fails to improve $\mathrm{SSI}$ rates, but increases antimicrobial resistance and the development of Clostridium difficile disease [20]. In our study, 8 (4.8\%) patients were positive for GDH and toxins A/B. Clostridial diarrhoea during antibiotic treatment for SWI is a serious complication, making the management of the initial clinical problem more difficult. Toxic megacolon associated Clostridium difficile colitis may be lethal in a patient with SWI following cardiac surgery.

It is of utmost importance to follow aseptic techniques strictly, use appropriate prophylactic antibiotics, and diagnose any infection early to decrease the incidence of SWI in the future. The knowledge of patient-related risk factors is important for choosing the appropriate empirical antibiotic therapy. Further studies are therefore necessary to determine the other SWI risk factors for patients who undergo cardiac surgery.

The data were obtained from medical records, which is an inherent limitation of retrospective studies. Secondly, only the swabs collected from the sternal wounds were taken into consideration. Patients were examined for signs of infection at the site of surgical incision on presentation to the ward, daily during the whole stay and on the discharge day, but by different nurses and doctors. Antibiotics used after discharge from hospital were not analysed in this study.

\section{Conclusions}

Sternal wound infection are common among patients with prolonged wound healing after cardiac surgery. Microorganisms associated with SWI in our study were mainly commensals, with the most common pathogen being Staphylococcus epidermidis.

\section{Acknowledgments}

The authors would like to express their gratitude towards the Hospital Infection Prevention and Control Team at our institution for their invaluable contribution to this study.

\section{Disclosure}

Authors report no conflict of interest.

\section{References}

1. Singh K, Anderson E, Harper JG. Overview and management of sternal wound infection. Semin Plast Surg 2011; 25: 25-33.

2. Lazar HL, Salm TV, Engelman R, Orgill D, Gordon S. Prevention and management of sternal wound infections. J Thorac Cardiovasc Surg 2016; 152: 962 972.
3. Litwinowicz R, Bryndza M, Chrapusta A, Kobielska E, Kapelak B, Grudzień G. Hyperbaric oxygen therapy as additional treatment in deep sternal wound infections - a single center's experience. Kardiochir Torakochir Pol 2016; 13: 198-202.

4. Cotogni P, Barbero C, Rinaldi M. Deep sternal wound infection after cardiac surgery: evidences and controversies. World J Crit Care Med 2015; 4: 265-273.

5. Galvao Tabosa do Egito J, Saad Abboud C, Vieira de Oliveira AP, Goncalves Maximo CA, Moreira Montenegro C, Lerner Amato V, Bammann R, Rarsky PS. Clinical evolution of mediastinitis in patients undergoing adjuvant hyperbaric oxygen therapy after coronary artery bypass surgery. Einstein 2013; 11: 345-349.

6. Howlader MH, Smith JEE, Madden BP. An approach to improve early detection of sternal wound infection. Bangladesh Med Res Counc Bull 2009; 35: 11-14.

7. Mills $C$, Bryson P. The role of hyperbaric oxygen therapy in the treatment of sternal wound infection. Eur J Cardiothorac Surg 2006; 30: 153-159.

8. Porubnicova I, Porubcin S, Sabol F. Jarcuska P. Risk factors predisposing to deep sternal wound infection. Kardiochir Torakochir Pol 2012; 12: 159-164.

9. Nespor D, Fabian J, Nemec PA. Retrospective analysis of deep sternal wound infections after longitudinal median sternotomy. Cor et Vasa 2015; 57: 75-81.

10. Cove ME, Spelman DW, MacLaren G. Infectious complications of cardiac surgery: a clinical review. J Cardiothorac Vasc Anesth 2012; 26: 1094-1100.

11. Slack RCB. Hospital infection. In: Medical Microbiology. A Guide to Microbial linfections: Pathogenesis, Immunity, Laboratory Diagnosis and Control. Greenwood D, Slack RCB, Peutherer JF, Barer MR (eds). Churchill Livingstone Elsevier, London 2007; 68: 693-701.

12. Annual epidemiological report 2014 - Antimicrobial resistance and health associated infection. Point prevalence survey of healthcare-associated infections (HAls) and antimicrobial use in European long-term care facilities, 2013. Available at: https://ecdc.europa.eu/sites/portal/files/media/en/ publications/Publications/antimicrobial-resistance-annual-epidemiologicalreport.pdf

13. Baron EJ, Miller JM, Weinstein MP, Richter SS, Gilligan PH, Thomson RB, Bourbeau P, Carroll KC, Kehl SC, Dunne WM, Robinson-Dunn B, Schwartzman JD, Chapin KC, Snyder JW, Forbes BA, Patel R, Rosenblatt JE, Pritt BS. A guide to utilization of the Microbiology Laboratory for Diagnosis of Infectious Diseases: 2013 Recommendations by the Infectious Diseases Society of America (IDSA) and the American Society for Microbiology (ASM). Clin Infect Dis 2013; 57: 22-121.

14. Falagas ME, Tansarli GS, Kapaskelis A, Vardakas KZ. Impact of vacuum-assisted closure (VAC) therapy on clinical outcomes of patients with sternal wound infections: a meta-analysis of non-randomized studies. PLoS 2013; 8: e64741.

15. Chaudhuri A, Shekar K, Coulter C. Post-operative deep sternal wound infections: making an early microbiological diagnosis. Eur J Cardiothorac Surg 2012; 41: 1304-1308.

16. Moinipoor AA, Abbasi M, Amouzeshi A, Esfahanizadeh J, Amini S. Deep sternal wound infection following cardiac surgery: epidemiology and causative germs. J Surg Trauma 2013; 1: 21-25.

17. Berrios-Torres SI, Umscheid CA, Bratzler DW, Leas B, Stone EC, Kelz RR, Reinke CE, Morgan S, Solomkin JS, Mazurski JE, Dellinger EP, Itani KMF, Berbari EF, Segreti J, Parvizi J, Blanchard J, Allen G, Kluytmans JAJW, Donaln R, Schecter WP. Centers for Disease Control and Prevention guideline for the prevention of surgical site infection, 2017. JAMA Surg 2017; 152: 784-791.

18. Montewka M, Skrzek A, Plewik D, Rudzki S, Wysokiński A, Kozioł-Montewka M. Zakażenia miejsca operowanego - charakterystyka czynników ryzyka, endogennych źródeł zakażenia i metody zapobiegania. Post Mikrobiol 2012; 51: 227-235.

19. Bertesteanu S, Traridis S, Stankovic M, Lazar V, Chifiriuc MC, Vlad M, Grigore R. Polymicrobial wound infections: pathophysiology and current therapeutic approaches. Int J Pharm 2014; 463: 119-126.

20. Hedrick TL, Smith PW, Gazoni LM, Sawyer RG. The appropriate use of antibiotics in surgery: a review of surgical infections. Cur Probl Surg 2007; 44: 635-675 